\title{
Differences on Language Structure between English and Indonesian
}

\author{
Acep Unang Rahayu
}

\begin{abstract}
This study is related to syntactic and semantic analyses. which analyses two main things : (1) Constructions of English Progressive Aspectuality (2) a. Gramatical meanings of progressive aspectuality and $\mathrm{b}$. Its correspondence in Indonesian. This research is limited only to the English constructions of be+V-ing. The data of this research were taken from English novels and their translations in Indonesian, and one collection of Indonesian short stories and its English translations translated by a native English speaker. In this research the thoughts of the English and Indonesian linguists are compared. In Indonesia Misunderstanding frequently take place in any situations especially in understanding written English, for examples: The problems for Indonesian students lie on understanding the meaning of English Progressive in the first place, and interpreting Indonesian Progressive sentences into English. Other English constructions such as Simple Present, Simple Past, Present or Past Perfect Simple have no problem in translating into Indonesian. That is why it is important to solve the problem to avoid misunderstanding. The author's contributions to this problem are as follows: explaining aspectuality of English progressive, teaching culture differences between English and Indonesian, and investigating English progressive correspondences in Indonesian.
\end{abstract}

Index Terms-Aspectuality, interpreting, meaning, progressive.

\section{INTRODUCTION}

As mentioned in the abstract above, In Indonesia English is as International language used as a compulsory language taught from elementary schools to tertiary levels, as a foreign language English should be mastered because most of the literature from many angles of knowledge is written in English. As itis known to have solid form of structure that deals with tense(s), English tenses are expressed using lexical signs in Indonesian language. This problem makes most of Indonesian students face difficulties in understanding spoken and written English. Other influencing problem is that the Indonesian structure is totally different from English. For example, in English, Subject is usually followed by a verb, while in Indonesian language, Subject can be followed by a noun or adjective. That is why in this presentation only progressive forms of English that will be discussed due to the limitation use of progressive forms of Indonesian language. For example the English progressive structure used such as Present Progressive, Past Progressive and Perfect Progressive have their correspondences in Indonesian Language, but other English Progressive structure such as Future Present

Manuscript received October 4, 2015; revised December 12, 2015.

Acep Unang Rahayu is with the Sekolah Tinggi Pariwisata Bandung (Bandung Tourism Institution), Indonesia (e-mail: acepurz@yahoo.com).
Progressive, Future Past Progressive, Future Present Perfect Progressive, and Future Past Perfect Progressive do not have their correspondences in Indonesian. Interpreting Indonesian into English sometimes is confusing because of the difference structure, meaning and cultural background. However, Interpreting English into Indonesian is considered easier. The language expressions of English progressive meaning in Indonesian language are so limited. For examples, English Present Progressive which are commonly translated as sedang, masih and lagi in Indonesian language can also be translated into sudah which is generally used for Perfect Progressive structure meaning. This is one of the other reasons why the analyses of structure differences and language expressions between English and Indonesian language need to be explored widely to limit the cultural differences gaps.

\section{LITERATURE REVIEWS}

Let us begin with some views about the term Aspectuality. Some say aspect, and others say aspectuality "[1] S. Heriyanto (200:76-77) cited Jacobson (1971) mentioned that "aspect deals with temporal values in inherent in the activity or state itself," "and Friedlich (1974) that" aspect signifies the relative duration or punctuality along a time line," Another view stated by "[2] B. Comrie (1978:15)" aspect are different ways of viewing the internal temporal constituency of a situation". In addition to that view "[3] L. J. Brinton (1990:5) aspect is subjective because the speaker chooses a particular viewpoint”. While "[4] S. G. Quirk (1973:25) who chose the term aspectuality mentioned that "aspectuality needs a choice between Perfect and non-Perfect," In addition to that "[5] S. G Quirk et.al. (1985:175-239) who agreed Aspectuality" as Aspect which denotes to grammatical cathegory whereby an action is related to time," An Indonesian expert "[6] T. F. Djajasudarma (1985:61) prefered the term Aspect to Aspectuality. She mentioned that Aspect is intern temporal structure of a situation that can be a condition, event and process". Similar to the citations [4] and [5] "[7] J. Lyons (1995:37) explained that "aspectuality derives from Russian word "Vid" which refers to perfective and imperfective differences". Other opinion by "[8] C. Murcia (1999:20) described that "aspectuality is related to an internal structure of action which happens anytime". He divided aspectuality to simple, perfect, progressive and the combination of perfect progressive". Supporting the others "[9] Binnick (2003:10) mentioned two kinds of aspectuality "imperfect aspectuality and continuous aspectuality". Agreeing with the previous researchers "[10] A. U. Rahayu (2007:52) described" aspectuality as a grammatical category which reflects the way an action of verb viewed from time space. He further 
mentioned that in English there are two kinds of aspectuality, those are Perfect and Imperfect (progressive) which are combined in verb frase and marked by at present or past". Finally “[11] M. Tadjuddin (1993:34) followed Bonarko (1971), Maslov (1978) and Dik (1989) mentioned that "we shall therefore use the pre-theoretical term 'aspectuality' to cover all these distinctions which are grammatically rather than lexically expressed".

\section{DISCUSSION}

The study of Aspectuality is rather rare in Indonesia, therefore many scholars find difficulties in getting sources. The term aspectuality and aspect sound confusing. What we know and understand about English structure is only English tense(s) sounding more familiar to both teachers and students. The thoughts described by some experts talking about this subject were more complicated than what we expected as linguists, besides that the talk of aspectuality is uncommon in Indonesia. However, that is linguistics, eventhough it needs deep thinking, it always is interesting to discuss. In Indonesia the English tenses are generally introduced in teaching English, and introducing tenses seems simpler than just talking about theoretical background. No wonder that the term aspectuality sounds strange to some Indonesian students as well as to the English lecturers. In fact, aspectuality is closely related to tenses. While aspectuality explains the inherent meaning, tenses describe when the situations take place. In my research, data were taken from English novels where situational conversations were chosen and selected as examples of English Aspectuality Progressive. Then the Indonesian translation of each situational conversations of Aspectuality Progressive were compared to find their correspondences.

The research aimed to find kinds of English Progressive Aspectuality and kinds of Indonesian grammatical meanings found in the constructions of English Progressive Aspectuality.

Here are few examples of English Progressive Aspectuality and their correspondences in Indonesian language taken from English novels No Greater Love (1991:15-306) and The Ranch (1997:95-203) by D. steele [12], [13] and their translations Yang Terkasih (2002:29-436) by I.K Hidayat [14] and Masih Ada Hari Esok (1999:84-158) by Ramayanti [15]. The Sky Is Falling ((2001:29-229) by S. Sheldon [16] and Its Translation Langit Runtuh (2005:38-234) by S. Hidayat [17]. From short stories Gonjong 2 Best Stories. A family Potrait (2001: 274) by R. Fanany [18] and the Indonesian translation Gonjong 2. Kumpulan Cerpen Terbaik. Potret keluarga (2001: 274) by I. Fanany [19].

\section{A. Present Progressive}

The data were taken from The Sky Is Falling and its translation Langit Runtuh .

1) "The police are investigating the cause of the accident".

2) "Polisi sedang menyelidiki penyebab kecelakaan".

In this example it is clear that the Present Progressive shows the action in progress (temporary situation in Indonesian kesementaraan). Its correspondence in Indonesian is also clear that the word "sedang" represents
Progressive Aspectuality. In other word there is no difficulty in translating English into Indonesian or vice versa. However, translating the above Indonesian sentence into English without time signals such as sekarang (now), saat ini (at the moment) is rather confusing, and may lead to misinterpretation. On the other hand translating the above English sentence is easier because the use of to be such as "are', though without time signal such as "now, or at the moment", represents the action at the moment or at the time of speaking.

\section{B. Past Progressive}

The data were taken from No Greater Love and its translation Yang Terkasih.

1) "She was saying above the din as the band launched into the ragtime".

2) "Yang sedang dikatakan Edwina dalam hiruk-pikuk suasana dermaga"

This sentence shows what some one was doing in the middle of a situation. In the English sentence above it is clear that the situation took place in the past. The Indonesian translation was rather vague if we read without knowing the context of the situation whether it happened in the past or in the present. A lone without time signal such as "dulu" which means in the past, such in "Yang sedang dikatakan Edwina dalam hiruk-pikuk suasana dermaga" the Indonesian translation above can mean the situation taking place in the present such as in this English sentence "She was saying above the din as the band launched into the ragtime". To note here, the lexical words "sedang and tengah" both refer to Simple Progressive correspondence.

\section{Perfect Progressive}

\section{1) Present perfect progressive}

The data were taken from The Ranch and its translation Masih Ada hari Esok.

1) "I've been letting him punish me"

2) "Inilah cara dia menghukumku"

This shows one of examples of a mismatch translation due to difference culture between English and Indonesian language. The Perfect Progressive tells unfinished past situations continuing to the present moment, while In Indonesian language we do not have this kind of Progressive situation. The English Perfect is generally translated "sudah or telah", while English Progressive is translated "sedang or lagi". However, in the context of Present Perfect Progressive above, the use of "sudah sedang", "sudah" that indicates Perfect, and "sedang" that indicates Progressive in the Indonesian translation, is omitted. So, both Present Perfect Simple and Present Perfect Progressive are mostly translated into Indonesian using "sudah". Because there is no proper expression in Indonesian language for Perfect Progressive. Hence, misinterpretation may occur. The above translation may be more proper translated as "Saya sudah membiarkan dia menghukumku".

\section{2) Past perfect progressive}

The data were taken from No Greater Love and its translation Yang terkasih.

1) "George hadn't been kidding when he said it".

2) "George tidak main-main mengatakannya". 
A different correspondence takes place in the above sentence. A common translation for this kind of Progressive should be the same as what has been explained in point 1 above. Where Perfect Simple, both Present or Past is translated "sudah or telah" In Indonesian language, but translation is found surprising that the use of "tidak main-main" which means not kidding as in the translation for Past Simple Progressive such as in "He was not kidding when He said it". The writer expected the above English Sentence would be translated as at least using "sudah" .In contrast to this situation, if the Past Perfect Progressive sentence above as in "George hadn't been kidding when he said it", and its Indonesian translation "George tidak main-main mengatakannya'. Using the word "sudah for perfect and "sedang" for Progressive for this translation will not be common in Indonesian language such as in" George sudah tidak sedang main-main mengatakannya". From this, I hope that we will learn that language and culture differences between English and Indonesian could be minimized. The invention of lexical expression in Indonesian for English Perfect Progressive should be made.

\section{Present Future Progressive}

The data were taken from The Sky Is Falling and its translation Langit Runtuh.

1) "I don't think I'll be coming back to Washington, Dana"

2) "aku rasa aku tidak akan kembali ke Washington Dana".

The other finding of my research as in this example in which the Indonesian word "sedang" is supposed to use normally for denoting progressiveness. In the translation above the word "sedang" is not used. The above translation is the same as the one used for expressing Simple Present Future such as in "I'll come back" and its translation is "aku akan kembali". Will is translated into "akan" in Indonesian. The negative sentence "I don't think" is "Saya rasa tidak", but in this example the negative word is translated in the Future sentence way as if it were "I won't be coming back". The flexibility in translating for this sentence takes place. However, the use of "sedang" after the word "akan" which refers to Future meaning in the translation will not sound strange. For example: "saya akan sedang kembali ke Washington" for "I'll be coming back to Washington "What we learn from this is that the inherent meaning of English Aspectuality Progressive should be understood to have better interpretation.

\section{E. Past Future Progressive}

The data were taken from No Greater Love and its translation Yang Terkasih.

1) "They would be sailing on her maiden voyage".

2) "Mereka akan menumpang kapal baru dalam pelayaran perdana ya".

In this example, the same case as in point 4 where the word "sedang" is not used. Therefore, it will be difficult to differ between Future Progressive "They would be sailing" and Future Simple "They would sail". The use of "sedang" in the translation will be acceptable as in" mereka akan sedang menumpang" which mean both English Progressive and its translation refer to a situation in progress. As a note, in this example the translator freely expresses her way of translating by putting the word "kapal baru" which means new ship that is not written in the English sentence above. In this example the translator may relate new ship to the sailing. So, we learn from here that translating or interpreting may mean explaining thing inherently.

\section{F. Modals with Progressive}

The data were taken from The Sky Is Falling and Langit Runtuh.

1) "The woman may be dying".

2) "Wanita itu mungkin akan meninggal".

In this example, the sentence a which refers to a situation in progress is translated in the same way as the Indonesian sentence is constructed. So, there is no problem in translating or expressing both English and Indonesia.

\section{G. Modals with Present Perfect}

The data were taken from The Ranch and its translation Masih Ada Hari esok.

1) "She must have been doing it for months".

2) "Dia pasti telah melakukannya selama berbulan-bulan".

Different from sentence a, in sentence c the word "sedang" which refers to a situation in progress is omitted. This may mean the same as we translate it into "She must have done it for months". So, what we learn from this example is that, English modals are translated properly in Indonesian, while the English Progressive sentence remains the same as it is an English Simple sentence.

To note here, there are still many other examples that the writer does not expose in this writing, due to limitation of the space. In my research there are some inherent meanings of English Aspectuality Progressive found such as: temporary, obligative, incoative, durative, habituative, continuative, intensive, comitative, probability, certainty, completive which do not always have their correspondences in Indonesian language.

\section{CONCLUSION}

Studying the above findings, I can conclude that culture interference is so dominating in our Indonesian language. Our language has limitation in terms of vocabulary which are almost roughly $50 \%$ borrowed from European languages such as from English, French, Spain, Italian and Dutch. The latest mention had ever occupied Indonesia for 3 and half decades. From Asia, Japan had occupied Indonesia for 3 and half years. These two occupiers must have influenced the development of our culture and language. Other countries which have influenced our culture are Chinese and Arabic. Almost 50\% Indonesia people are Chinese-Indonesian breeds, and majority of our people have a religion belief of Moslem. The rest religion believers are Christian, Hindu, Budha and others.

Returning to the discussion about the difference on language structure between English and Indonesian, and the focus of attention in this discussion is on English Aspectuality Progressive, the writer hopes that both English and Indonesian users will be able to understand each intended meaning in English Aspectuality Progressive and their correspondence in Indonesian.

Finally, I would recommend that the introduction of 
English Aspectuality Progressive should be enhanced besides introducing English Progressive Tenses, and the invention of English Progressive expressions or correspondences in Indonesian language should be made.

\section{REFERENCES}

[1] S. Heriyanto, "Kajian sintaksis dan semantis frasa verba bahasa Inggris tipe close-knit, catenative $+\mathrm{V}, \mathrm{V} 1+\mathrm{V}$ dan gradasi keseratan hubungan antar unsur pembentuknya, serta padanannya dalam bahasa Indonesia," Doctoral Dissertation Program Pascasarjana UNPAD Bandung, Indonesia, pp. 76-77, October 2002.

[2] B. Comrie, Aspect, Cambridge: Cambridge University Press, 1978, p. 15.

[3] L. J. Brinton, The Development of English Aspectual System, Cambridge University press, 1990, p. 5.

[4] S. G. Quirk, A University Grammar of English, Hongkong: Longman Group, 1973, p. 25.

[5] Quirk et al., A Comprehensive Grammar of English Language, New York: Longman, 1985, pp. 175-239.

[6] T. F. Djajasudarma, "Kecap anteuran bahasa sunda: Kajian semantik dan struktur," Doctoral Dissertation, Universitas Indonesia, p. 61, 1985.

[7] J. Lyons, "Pengantar ilmu linguistik," P.T. Gramedia Pustaka Utama, Jakarta, Indonesia, p. 37, 1995.

[8] C. Murcia, Grammar Book: An ESL/EFL Teacher's Course, 2nd ed. USA: Heinle and Heinle Publishers, 1999, p. 20.

[9] J. Binnick. (2003). Tense, verbal aspect, aktionsart and related areas. [Online]. p. 10. Available: http//www.Invisiblelighthouse.com/langtab aspect.html

[10] A. U. Rahayu, "The English progressive aspectuality and its correspondence in Indonesian (structure and semantic analyses)," A Doctoral Dissertation, Padjadjaran University Bandung, Indonesia, 2007, p. 52.

[11] M. Tadjuddin, "Pengungkapan makna aspektualitas bahasa rusia dalam bahasa Indonesia. suatu telah tentang aspek dan aktionsart," Depdikbud, Indonesia, p. 34, 1993.
[12] D. Steel, No Greater Love, New York: Dell Publishing Inc., 1991, pp 15-306.

[13] D. Steel, The Ranch, New York: Dell Publishing Inc., 1997, pp. 95-203.

[14] I. K. Hidayat, "Yang terkasih," PT. Gramedia Pusaka Utama, Jakarta, Indonesia, pp. 29-436, 2002.

[15] Ramayanti, "Masih ada hari esok," C. V. Karyono, Yogyakarta, Indonesia, pp. 84-158, 1999.

[16] S. Sheldon, "The Sky Is Falling," Harper Collins Publishers. Inc. U.S.A., pp. 29-229, 2001.

[17] S. Hidayat, "Langit runtuh," P.T. Gramedia Pustaka Utama, Jakarta, Indonesia, pp. 38-234, 2005.

[18] R. Fanany, "Gonjong 2," Best Short Stories - A Family Portrait, Deakin University Melbourne, Australia, p. 274, 2001.

[19] I. Fanany, “Gonjong 2," Kumpulan Cerpen Terbaik - Potret Keluarga, Pusat Kajian Humaniora, Universitas Negeri Padang, Indonesia, Program Bahasa Indonesia, p. 274, 2001.

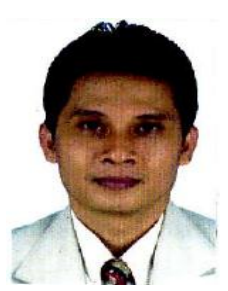

Acep Unang Rahayu was born on November 22, 1964 in Bandung, Indonesia. He graduated from Institute of Teaching and Education, Bandung, Indonesia in 1990. He received his master's degree in TESOL from Leeds University, U.K. in 1994. Then, he received his doctorate degree in linguistics from Padjadjaran University Bandung, Indonesia in 2007.

$\mathrm{He}$ is a senior English lecturer interested in applied and pure linguistics. His permanent job is at Bandung Tourism Higher Education, Indonesia under the Ministry of Tourism and culture. He also publishes his research findings on domestic journals. His book publication is How to Make an Academic Essay Writing (Bandung, Indonesia, Pt. Alfabetha, 2015). He has been doing some research on language, social, motivation, human resources, cultural and others.

Dr. Rahayu joined an Indonesian Linguistics Society from 2001 to 2007 , and got awards from Indonesian President in 2004 for his loyalty as a civil servant employee, as well as in 2012. 